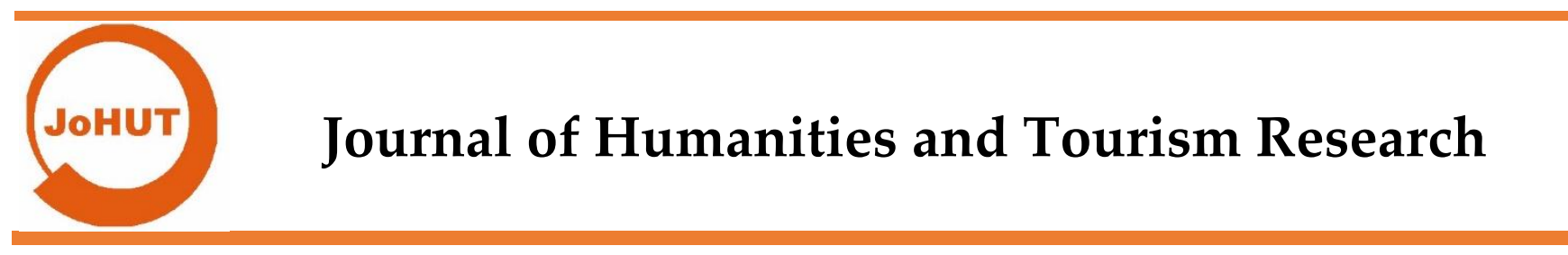

Araştırma Makalesi

\title{
Ergenlerde Arkadaşlık İlişkileri ve Akran Sapması
}

\section{Friendship Relationships and Peer Deviation in Adolescents}

${ }^{1}$ Iğdır Üniversitesi, Tuzluca Meslek Yüksekokulu, Iğdır, Türkiye

${ }^{2}$ Karabük Üniversitesi Sağlık Bilimleri Fakültesi, Karabük, Türkiye

ORCID:

D.A.: 0000-0002-3083-7202

A.Ö.: 0000-0001-9043-0407

\section{Corresponding Author:}

Arzu ÖZYÜREK

Email:

a.ozyurek@karabuk.edu.tr

Citation: Atalay, D. ve Özyürek, A. (2020). Ergenlerde arkadaşlik ilişkileri ve akran sapması. Journal of Humanities and Tourism Research, 10 (2): 249-261.

Submitted: 06.03.2020

Accepted: 18.03.2020

\section{Derya ATALAY ${ }^{1}$, Arzu ÖZYÜREK²}

\section{Özet}

$\mathrm{Bu}$ araştırmanın amaci, ergenlerde arkadaşlik ilişkileri ve akran sapmasinın incelenmesidir. Çalışma grubunu ortaokul 7. ve 8.sını öğrencisi 500 ergen oluşturmuştur. Verilerin toplanmasında Arkadaş İlişkileri ve Akran Sapması Ölçeği kullanılmıştır. Veriler analizinde Mann Whitney U, Kruskal Wallis HTesti ve Spearman Brown Korelasyon Analizi kullanılmıştır. Araştırma sonucunda, erkeklerin akran sapmasının kızlardan daha yüksek olduğ u belirlenmiștir. Kız ergenlerin erkeklere göre arkadas ilișkilerinde daha fazla güven ve özdeşim ile sadakate sahip oldukları, erkeklerin ise arkadaş ilişkilerinde daha fazla kendilerini açtıkları belirlenmiştir. Ergenlerin akran sapması ve arkadaş ilişkileri ile kardeş sayısı, anne-baba yaşı arasında anlamlı fark olmadı ̆̆ı $(p>0,05)$ belirlenmiştir. Akran sapması anne öğrenim durumundan etkilenmezken annesi ilkokul mezunu ergenlerin arkadaş ilişkilerinde bağhllık oranının diğerlerinden daha yüksek olduğu saptanmıştır. Akran sapması ile ergenlerin arkadaşlık ilişkileri arasında manidar bir ilişki saptanmiştır.

Anahtar Sözcükler: Akran Sapması, Arkadaşlık Illişkileri, Ergenlik Dönemi

\section{Abstract}

The aim of this study is to examine friendship relations and peer deviation in adolescents. The study group consisted of 500 adolescents from secondary school grades 7 and 8. The "Friendship Relations Scale" and "Peer Deviation Scale" were used to collect data. Mann Whitney U., Kruskal Wallis H-Tests and Spearman Brown Correlation Analysis were used to analyze the data. As a result of the research, it has been determined that peer deviation of males is higher than that of females. It has been determined that female teenagers have more reliability and identification in friendship relations, and male teenagers open themselves more in friendship relations. It is found that there is no significant difference between the number of siblings and the age of the mother and father with peer deviation and friendship relations in teenagers ( $p>0.05)$. It is found that the mother's education status has not affected the peer deviation; although devotion rate in friendship relations was higher for teenagers whose mothers graduated from primary school than for others. Also it is found that there is a significant relation between peer deviation with friendship relations.

Keywords: Peer Diversion, Friendship Relationships, Adolescence Period. 


\section{GİRİş}

Gelişimsel açıdan hızlı değişimlerin yaşandığı ergenlik dönemi, üzerinde önemle durulması gereken bir dönemdir. Çünkü bu dönemde birey, kimliğini oluşturmak, kendi değer yargılarını belirlemek, özdenetim geliştirmek, zihinsel becerilerini geliştirmek gibi gelişim süreçlerinden geçmektedir. Çocukluk ve gençlik arasındaki geçiş dönemi olarak da nitelendirilebilen bu dönemde, gelişim sürecinden geçen bireylerin farklı davranış ve tepkiler göstermesi söz konusu olabilmektedir. Bu dönemde, kişilerarası ilişkilerin de sürece dahil olması, durumu daha karmaşık hale getirebilmektedir.

Kişiler arası ilişkilerin sağlıklı bir şekilde sürdürülmesinde pek çok unsur etkilidir. $\mathrm{Bu}$ unsurlar kendini açma, güvenme ve özdeşim kurma, sadakat ve bağlllık olarak ele alınabilir. Güvengenlik, bireyin başkalarıyla ilişkilerinde kendinden ödün vermeden ve karşısındakinin de hakkını koruyarak kendisini açık şekilde ifade etmeye dayalıdır (Uz-Baş, 2012). Kendini açma ise, bireyin başkalarıyla kendisi hakkındaki bilgileri paylaşma sürecidir ve geçmiş yaşantılar, güncel olaylar, gelecekle ilgili beklentiler vb. açığa vurulur. Kendini açma, gelişi güzel veya özel sırların ve durumların her karşılaşılan kişiye anlatılması anlamı taşımaz. Ancak güven duyulan kişilere uygun şartlarda yapılabilir (Çetinkaya, 2012). Sadakat; dostluk, içten bağlılık, doğruluk, vefa anlamına gelmektedir (www.tdk.gov.tr). Diğer bireylerle ilişki kurmak ve yakınlık arayışı ihtiyacını ifade eden bağlanma ise bebeklikte anneye yönelikken ergenlikte arkadaşlara yöneliktir. Sağlıklı iletişimin gerekli bu unsurların tümü, ergenlik döneminde arkadaşlık ilişkileri üzerinde oldukça etkilidir (Deniz, 2006).

Kuramsal açıdan bakıldığında, ergenlik dönemi kimlik kazanımının tamamlanması gereken bir dönemdir. Erikson, gelişimsel kuramında ergenlik döneminde baş edilmesi gereken çatışma durumunu kimlik kazanımına karşı kimlik bunalımı olarak ele almıştır. Ergenin toplumsal, cinsel veya mesleki kimlik kazanımında, aileden çok arkadaş ilişkileri ön planda olabilir (Yalom, 2008). Arkadaşlık bireyin yaşamının her döneminde gereken, ortak tutumlar ve davranış kalıplarının paylaşıldığı veya yeni tutum ve davranış kalıplarının oluştuğu, iletişim gruplarının özelliklerini taşıyan toplumsal bir birimdir (Köknel,1997). Arkadaşlık ilişkilerine yüklenen anlam, bireyin yaşıyla birlikte değişmektedir (Hartup ve Stevens, 1997). Arkadaşlar boş zaman aktivitelerini, inanç ve değerlerini paylaşırlar. Kitap, video oyunları ve filmler vb. hakkında bilgi alışverişinde bulunur, ilgi duydukları konuları tartışarak zamanlarının çoğunu gruplar ve kalabalık çevrelerde harcarlar. Ergenlikteki arkadaşlıklar ergenin benlik saygısını artırma ve sosyal becerilerini geliştirmede önemli bir fırsat sunmaktadır. Ergen, arkadaşlık ilişkileri sayesinde bir gruba ait olma ve kendi gelişimini daha doğru değerlendirme fırsatı elde etmektedir (Sayıl, Uçanok ve Güre, 2002; Durmuşoğlu ve Doğru, 2006).

Arkadaşlığın işlevleri bir gruba ait olma duygusu, duygusal bütünlük ve kararlılık oluşturma, iletişim sağlama, değerli olduğunu hissetme, diğerlerine yardım etme fırsatı sağlama ve kişiliği destekleme olarak özetlenebilir. Bir geçiş dönemi olan ergenlikte, bir gruba ait olma gereksinimi üst düzeydedir. Grubun bir parçası olmak için ergen büyük fedakârlıkta bulunur, çoğu enerjisini arkadaşlık kurmaya ve grup içinde yer edinmeye harcar. Ergenlik dönemi okul çağ1 içerisinde olduğundan ergen ailesinden çok arkadaşlarıyla etkileşime girer ve onlarla daha fazla zaman geçirir. Akranlarıyla ilişkileri, ergenlerin cinsiyet rollerini öğrenip edinmelerine yardım etmektedir. Karşı cinse olan ilgi ve karşı cinsin beğenisini kazanma çabası artmıştır. Akran ilişkilerinde güvenirlik, yardımseverlik, dürüstlük gibi değerler ön plana çıktığından arkadaşlık ilişkileri daha da önemli hale gelir (Çevik ve Atıcı, 2008).

Ergenlik döneminde, aile istenilen davranışı kazandırmada arkadaş grubu kadar etkili değildir (Demir, Baran ve Ulusoy 2005). Bu bağlamda bireylerin olumsuz davranışları arkadaşlarından öğrendikleri söylenebilir. Ergenlik dönemindeki ilişkiler yapıcı veya yıkıcı 
özellikte olabilir. İyi arkadaşlarla olan ilişkiler bireye olumlu davranışlar kazandırırken istenmeyen davranışlara sahip olan arkadaşlar bireyde olumsuz davranışların kazanılmasına neden olabilmektedir (Ekşi, 2013). Doyasıyla arkadaşlık ilişkileri, ergenlerde sapma durumlarına da neden olabilecektir. Toplum tarafından kabul görmeyen suça yönelme, madde kullanma ve madde bağımlılığı, arkan zorbalığı gibi sapma davranışları arkadaşlık ilişkileriyle edinilebilir. Bir gruba dahil olma çabasının görüldüğü ergenlik döneminde, bu sapma davranışlarının daha fazla ortaya çıkabilir. Ancak arkadaşlık ilişkilerinin olumlu düzeyde seyretmesi, olumsuz davranışlara yönelmeyi engelleyebilir.

Alan yazında ergenlik döneminde arkadaşlık ilişkilerinin demografik değişkenlere göre incelendiği bazı çalışmalar bulunmaktadır (Tozkoparan, 2014; Şimsek, 2010; Dinçer, 2008; Döğücü, 2004; Delikara, 2000; Davies ve Brember, 1999; Hortaçsu ve Oral, 1991; Moore ve Boldero, 1991). Bu çalışmada ise demografik bazı değişkenler yanında arkadaşlık ilişkileri ve akran sapması arasında bir ilişki olup olmadığını araştırmak amaçlanmıştır. Şu sorulara cevap aranmıştır:

- Ergenlerin arkadaşlık ilişkileri ve akran sapması cinsiyet, kardeş sayısı, anne-baba yaşı ve öğrenim durumuna göre farklılık göstermekte midir?

- Ergenlerin arkadaşlık ilişkileri ve akran sapması arasında anlamlı bir ilişki bulunmakta midır?

\section{YÖNTEM}

\subsection{Araştırma Deseni}

Nicel olarak tasarlanan çalışmada, betimsel tarama modeli kullanılmıştır. Betimsel taramada, bir durumu var olduğu şekliyle betimlemek amaçlanmaktadır (Sönmez ve Alacapınar, 2011). Bir problem veya olayın ne olduğu açıklanmaya çalışılır ve çok sayıda birey üzerinde, belli bir zaman içinde yapılır. Betimleme sayesine olaylar veya olgular daha iyi anlaşılabilir (Kaptan, 1998). Bu araştırmada ise ergenlerin arkadaşlık ilişkilerindeki becerileri betimlenmeye çalışılmıştır.

\section{2. Çalışma Grubu}

Çalışma grubu, Karabük İl merkezi ve ilçelerinde 2016-2017 eğitim-öğretim yılında MEB'e bağlı ortaokullardan kolay ulaşılabilir örnekleme yöntemiyle rastlantısal olarak seçilen okullardan 7. ve 8. sınıf öğrencisi, 251'i kız, 249'u erkek, toplam 500 ergenden oluşmuştur.

\subsection{Veri Toplama Araçları}

Verilerin toplanmasında Kaner'in (1998) geliştirmiş olduğu Arkadaş İlişkileri Ölçeği ve Akran Sapması Ölçeği kullanılmıştır. Arkadaş İlişkileri Ölçeği ergenlerin arkadaşlarıyla ilgili duygu ve düşüncelerini belirlemek amacıyla, Akran Sapması Ölçeği statü suçu olarak kabul edilen davranışların yanı sıra yakalandıklarında suç kabul edilip gençlerin yargı sistemiyle karşı karşıya gelmelerine neden olabilecek davranışları içeren bir ölçektir. Her İki ölçek formu Ankara'da 14 ila 18 yaşları arasında 1648 ergene uygulanmıştır. Akran İlişkileri Ölçeği'nin Bağlılık, Güven ve Özdeşim, Kendini Açma, Sadakat olmak üzere dört faktörlü 18 maddelik yapıya sahip olduğu belirlenmiştir. Likert tipindeki ölçeğin Cronbach Alfa güvenirlik katsayısı 0,86, Spearman Brown test yarılama güvenlik katsayısı 0,73 olarak bulunmuştur. Ayrıca 60 kişilik bir gruba tekrar uygulanan ölçeğin test-tekrar test güvenirlik katsayısı 0,93 olarak belirlenmiştir. Alınan yüksek puanlar, arkadaşlarla olan ilişkilerin olumlu olduğu şeklinde yorumlanır. Toplam 14 maddelik Akran Sapması Ölçeği ise Hafif Sapma ve Ağır Sapma olmak üzere iki faktörden oluşmaktadır. Ölçeğin güvenirliği Cronbach Alpha iç tutarlılık, iki yarım test güvenirliği, test tekrar test yöntemi ile incelenmiş ve sonuçlar ölçeğin psikometrik özelliklerinin yeterli olduğunu göstermiştir. Alının yüksek puanlar, hafif ya da ağır sapma düzeyini göstermektedir. Farklı bir çalışma grubu ele 
alındığından bu çalışmada güvenirlik katsayılarına bakılmış ve Akran İlişkileri Ölçeği için Cronbach Alpha güvenirlik katsayısı 0,83, Akran Sapması Ölçeği için 0,86 olarak belirlenmiştir.

\subsection{Verilerin Toplanması ve Analizi}

Verilerin toplama araçları ortaokul 7.-8. sınıf öğrencilerine sınıf ortamında uygulanmıştır. Elde edilen veriler bilgisayar ortamına girilmiş, Kolmogorov-Smirnov ve Shapiro Wilk değerlerine göre verilerin normal dağılımdan gelmemesi nedeniyle verilerin analizinde Mann Whitney-U ve Kruskal Wallis-H Testleri uygulanmıştır (Büyüköztürk, 2016). İki ölçüm seti arasındaki ilişkinin belirlenmesinde Spearman Brown Korelasyon katsayısı kullanılmıştır

\section{BULGULAR}

Tablo 1'de AïÖ ve ASÖ puanlarının ergenlerin cinsiyetine, Tablo 2'de kardeş sayısına göre analiz sonuçları

Tablo 1. Cinsiyete Göre AïÖ ve ASÖ Puanları MWU Test Sonuçları

\begin{tabular}{|c|c|c|c|c|c|c|c|}
\hline AİÖ & Cinsiyet & $\mathrm{n}$ & Ort. & Ss & Sira Ort. & $\mathrm{z}$ & $\mathrm{p}$ \\
\hline \multirow{2}{*}{ Bağlilık } & $\mathrm{K}_{1 \mathrm{z}}$ & 251 & 14,04 & 6,16 & 245,40 & \multirow{2}{*}{$-0,796$} & \multirow{2}{*}{0,426} \\
\hline & Erkek & 249 & 14,27 & 5,94 & 255,64 & & \\
\hline \multirow{2}{*}{ Güven ve Özdeşim } & $\mathrm{K}_{12}$ & 251 & 8,47 & 3,59 & 276,27 & \multirow{2}{*}{$-4,036$} & \multirow{2}{*}{$0,001^{*}$} \\
\hline & Erkek & 249 & 7,26 & 3,12 & 224,52 & & \\
\hline \multirow{2}{*}{ Kendini Açma } & $\mathrm{K}_{1 z}$ & 251 & 9,84 & 3,13 & 232,28 & \multirow{2}{*}{$-2,847$} & \multirow{2}{*}{$0,004^{*}$} \\
\hline & Erkek & 249 & 10,64 & 3,05 & 268,87 & & \\
\hline \multirow{2}{*}{ Sadakat } & $\mathrm{K}_{12}$ & 251 & 12,36 & 2,57 & 284,23 & \multirow{2}{*}{$-5,288$} & \multirow{2}{*}{$0,001^{*}$} \\
\hline & Erkek & 249 & 11,10 & 2,83 & 216,50 & & \\
\hline \multicolumn{8}{|l|}{ ASÖ } \\
\hline \multirow{2}{*}{ Hafif Sapma } & $\mathrm{K}_{1 z}$ & 251 & 10,96 & 2,92 & 225,32 & \multirow{2}{*}{$-3,946$} & \multirow{2}{*}{$0,001^{*}$} \\
\hline & Erkek & 249 & 12,29 & 4,21 & 275,88 & & \\
\hline \multirow{2}{*}{ A ğır Sapma } & $\mathrm{K}_{1 \mathrm{Z}}$ & 251 & 6,21 & 0,59 & 236,40 & \multirow{2}{*}{$-3,131$} & \multirow{2}{*}{$0,002^{*}$} \\
\hline & Erkek & 249 & 6,81 & 2,96 & 264,71 & & \\
\hline
\end{tabular}

Tablo 1'e göre, AİÖ Güven ve Özdeşim, Kendini Açma, Sadakat alt boyut puanları ve ASÖ Hafif ve Ağır Sapma alt boyut puanları ile ergenlerin cinsiyeti arasında manidar fark vardır $(\mathrm{p}<0,05)$. Erkeklerin AİÖ Güven ve Özdeşim alt boyut puanı $(\bar{X}=7,26)$ ile Sadakat alt boyut puanı $(\bar{X}=11,10)$, kızların Güven ve Özdeşim alt boyut puanı $(\bar{X}=8,47)$ ile Sadakat alt boyut puanına $(\bar{X}=12,36)$ göre istatistiksel olarak anlamlı derecede düşüktür. Kızların AïÖ Kendini Açma alt boyut puanı $(\bar{X}=9,84)$ erkeklerin AïÖ Kendini Açma alt boyut puanından $(\bar{X}=10,64)$ istatistiksel olarak anlamlı düzeyde düşüktür. Kızların ASÖ Hafif Sapma $(\bar{X}=10,96)$ ve ASÖ Ağır Sapma alt boyut puanı $(\bar{X}=6,21)$, erkeklerin ASÖ Hafif Sapma $(\bar{X}=12,29)$ ve Ağır Sapma alt boyut puanına $(\bar{X}=6,81)$ göre istatistiksel olarak anlamlı derecede düşüktür. 
D. Atalay, A. Özyürek

Tablo 2. Kardeş Sayısına Göre AïÖ ve ASÖ Puanları KWH Test Sonuçları

\begin{tabular}{|c|c|c|c|c|c|c|c|}
\hline AİÖ & & $\mathrm{n}$ & Ort. & Ss & Sira Ort. & $\mathrm{H}$ & $\mathrm{p}$ \\
\hline \multirow{4}{*}{ Bağlılık } & Tek çocuk & 43 & 13,88 & 5,88 & 243,47 & \multirow{4}{*}{1,039} & \multirow{4}{*}{0,792} \\
\hline & İki kardeş & 214 & 14,15 & 6,40 & 244,90 & & \\
\hline & Üç kardeş & 169 & 14,01 & 5,64 & 254,21 & & \\
\hline & Dört ve üzeri & 74 & 14,64 & 6,06 & 262,32 & & \\
\hline \multirow{4}{*}{ Güven ve Özdeşim } & Tek çocuk & 43 & 7,35 & 3,62 & 219,22 & \multirow{4}{*}{2,809} & \multirow{4}{*}{0,422} \\
\hline & İki kardeş & 214 & 8,05 & 3,46 & 258,69 & & \\
\hline & Üç kardeş & 169 & 7,85 & 3,44 & 249,87 & & \\
\hline & Dört ve üzeri & 74 & 7,69 & 3,11 & 246,43 & & \\
\hline \multirow{4}{*}{ Kendini Açma } & Tek çocuk & 43 & 10,44 & 2,87 & 259,45 & \multirow{4}{*}{1,411} & \multirow{4}{*}{0,703} \\
\hline & İki kardeş & 214 & 10,13 & 3,24 & 244,98 & & \\
\hline & Üç kardeş & 169 & 10,19 & 3,01 & 248,31 & & \\
\hline & Dört ve üzeri & 74 & 10,54 & 3,13 & 266,26 & & \\
\hline \multirow{4}{*}{ Sadakat } & Tek çocuk & 43 & 12,07 & 2,61 & 266,78 & \multirow{4}{*}{2,496} & \multirow{4}{*}{0,476} \\
\hline & İki kardeş & 214 & 11,59 & 2,73 & 241,16 & & \\
\hline & Üç kardeş & 169 & 11,93 & 2,73 & 260,90 & & \\
\hline & Dört ve üzeri & 74 & 11,51 & 3,08 & 244,30 & & \\
\hline ASÖ & Tek çocuk & & & & & \multirow{5}{*}{4,922} & \multirow{5}{*}{0,178} \\
\hline \multirow{4}{*}{ Hafif Sapma } & İki kardeş & 43 & 11,09 & 3,43 & 221,60 & & \\
\hline & Üç kardeş & 214 & 11,57 & 3,89 & 241,63 & & \\
\hline & Dört ve üzeri & 169 & 11,91 & 3,79 & 267,15 & & \\
\hline & Tek çocuk & 74 & 11,39 & 2,86 & 254,91 & & \\
\hline \multirow{4}{*}{ Ağır Sapma } & İki kardeş & 43 & 6,33 & 0,87 & 242,36 & \multirow{4}{*}{3,126} & \multirow{4}{*}{0,373} \\
\hline & Üç kardeş & 214 & 6,53 & 2,47 & 243,80 & & \\
\hline & Dört ve üzeri & 169 & 6,54 & 2,23 & 254,45 & & \\
\hline & Tek çocuk & 74 & 6,47 & 1,41 & 265,59 & & \\
\hline
\end{tabular}

Tablo 2'de görüldüğü gibi, ergenlerin AïÖ ve ASÖ puanlarının kardeş sayısına göre anlamlı bir farklılık göstermediği tespit edilmiştir $(\mathrm{p}>0,05)$.

Tablo 3'te AIÖ ve ASÖ puanlarının ergenlerin anne yaşına ve Tablo 4'te baba yaşına göre analiz sonuçları sunulmuştur. 
Tablo 31. Anne Yaşına Göre AİÖ ve ASÖ Puanları KWH Test Sonuçları

\begin{tabular}{|c|c|c|c|c|c|c|c|}
\hline AİÖ & & $\mathrm{n}$ & Ort. & Ss & $\begin{array}{l}\text { Sira } \\
\text { Ort. }\end{array}$ & $\mathrm{H}$ & $\mathrm{p}$ \\
\hline \multirow{3}{*}{ Bağlilık } & 35 yaş ve altı & 216 & 13,73 & 5,63 & 242,44 & \multirow{3}{*}{1,196} & \multirow{3}{*}{0,550} \\
\hline & $36-40$ yaş & 183 & 14,40 & 6,12 & 256,99 & & \\
\hline & 41 yaş ve üstü & 101 & 14,60 & 6,72 & 255,98 & & \\
\hline \multirow{3}{*}{ Güven ve Özdeşim } & 35 yaş ve altı & 216 & 7,87 & 3,40 & 251,52 & \multirow{3}{*}{0,060} & \multirow{3}{*}{971} \\
\hline & $36-40$ yaş & 183 & 7,81 & 3,22 & 251,00 & & \\
\hline & 41 yaş ve üstü & 101 & 7,96 & 3,78 & 247,42 & & \\
\hline \multirow{3}{*}{ Kendini Açma } & 35 yaş ve altı & 216 & 10,15 & 3,23 & 247,24 & \multirow{3}{*}{0,458} & \multirow{3}{*}{0,795} \\
\hline & $36-40$ yaş & 183 & 10,20 & 3,18 & 249,73 & & \\
\hline & 41 yaş ve üstü & 101 & 10,48 & 2,72 & 258,86 & & \\
\hline \multirow{3}{*}{ Sadakat } & 35 yaş ve altı & 216 & 11,74 & 2,80 & 251,42 & \multirow{3}{*}{0,596} & \multirow{3}{*}{0,742} \\
\hline & $36-40$ yaş & 183 & 11,83 & 2,70 & 254,61 & & \\
\hline & 41 yaş ve üstü & 101 & 11,55 & 2,85 & 241,09 & & \\
\hline \multicolumn{8}{|l|}{ ASÖ } \\
\hline \multirow{3}{*}{ Hafif Sapma } & 35 yaş ve altı & 216 & 11,73 & 3,98 & 253,57 & \multirow{3}{*}{0,631} & \multirow{3}{*}{0,729} \\
\hline & $36-40$ yaş & 183 & 11,54 & 3,64 & 243,90 & & \\
\hline & 41 yaş ve üstü & 101 & 11,51 & 3,03 & 255,90 & & \\
\hline \multirow{3}{*}{ Ağır Sapma } & 35 yaş ve altı & 216 & 6,58 & 2,66 & 250,81 & \multirow{3}{*}{1,639} & \multirow{3}{*}{0,441} \\
\hline & $36-40$ yaş & 183 & 6,54 & 1,94 & 255,96 & & \\
\hline & 41 yaş ve üstü & 101 & 6,29 & 0,94 & 239,94 & & \\
\hline
\end{tabular}

Tablo 3'te görüldüğü gibi Aî̈Ö ve ASÖ tüm puanlarının anne yaşına göre anlamlı bir farklılık göstermediği tespit edilmiştir ( $p>0,05)$. 
D. Atalay, A. Özyürek

Tablo 4. Baba Yaşına Göre AİÖ ve ASÖ Puanları KWH Test Sonuçları

\begin{tabular}{|c|c|c|c|c|c|c|c|}
\hline AİÖ & & $\mathrm{n}$ & Ort. & Ss & $\begin{array}{l}\text { Sira } \\
\text { Ort. }\end{array}$ & $\mathrm{H}$ & $\mathrm{p}$ \\
\hline \multirow{3}{*}{ Bağllılık } & 35 yaş ve altı & 87 & 14,19 & 6,03 & 251,79 & \multirow{3}{*}{1,039} & \multirow{3}{*}{0,595} \\
\hline & $36-40$ yaş & 211 & 13,77 & 5,79 & 243,20 & & \\
\hline & 41 yaş ve üstü & 202 & 14,53 & 6,30 & 257,57 & & \\
\hline \multirow{3}{*}{ Güven ve Özdeşim } & 35 yaş ve altı & 87 & 8,20 & 3,58 & 264,62 & \multirow{3}{*}{4,377} & \multirow{3}{*}{0,112} \\
\hline & $36-40$ yaş & 211 & 7,48 & 3,19 & 234,89 & & \\
\hline & 41 yaş ve üstü & 202 & 8,13 & 3,54 & 260,73 & & \\
\hline \multirow{3}{*}{ Kendini Açma } & 35 yaş ve altı & 87 & 9,97 & 3,03 & 240,10 & \multirow{3}{*}{0,588} & \multirow{3}{*}{0,745} \\
\hline & $36-40$ yaş & 211 & 10,24 & 3,26 & 251,37 & & \\
\hline & 41 yaş ve üstü & 202 & 10,34 & 2,99 & 254,07 & & \\
\hline \multirow{3}{*}{ Sadakat } & 35 yaş ve altı & 87 & 11,75 & 2,91 & 254,71 & \multirow{3}{*}{0,099} & \multirow{3}{*}{0,952} \\
\hline & $36-40$ yaş & 211 & 11,71 & 2,79 & 249,00 & & \\
\hline & 41 yaş ve üstü & 202 & 11,76 & 2,71 & 250,26 & & \\
\hline \multicolumn{8}{|l|}{ ASÖ } \\
\hline \multirow{3}{*}{ Hafif Sapma } & 35 yaş ve altı & 87 & 11,36 & 2,85 & 251,91 & \multirow{3}{*}{0,502} & \multirow{3}{*}{0,778} \\
\hline & $36-40$ yaş & 211 & 11,69 & 4,10 & 245,37 & & \\
\hline & 41 yaş ve üstü & 202 & 11,65 & 3,53 & 255,25 & & \\
\hline \multirow{3}{*}{ Ağır Sapma } & 35 yaş ve altı & 87 & 6,37 & 0,83 & 257,78 & \multirow{3}{*}{0,558} & \multirow{3}{*}{0,757} \\
\hline & $36-40$ yaş & 211 & 6,58 & 2,69 & 248,45 & & \\
\hline & 41 yaş ve üstü & 202 & 6,49 & 1,90 & 249,50 & & \\
\hline
\end{tabular}

Tablo 4'te görüldüğü gibi, ergenlerin AiIÖ ve ASÖ puanlarının baba yaşına göre anlamlı bir farklılık göstermediği tespit edilmiştir $(p>0,05)$.

Tablo 5'te AİÖ ve ASÖ puanlarının ergenlerin anne ve Tablo 6' da baba öğrenim durumuna göre analiz sonuçları sunulmuştur. 
Tablo 5. Anne Öğrenimine Göre AİÖ ve ASÖ Puanları KWH Test Sonuçları

\begin{tabular}{|c|c|c|c|c|c|c|c|}
\hline Aİ̈ & & $\mathrm{n}$ & Ort. & Ss & $\begin{array}{l}\text { Sira } \\
\text { Ort. }\end{array}$ & $\mathrm{H}$ & $\mathrm{p}$ \\
\hline \multirow{4}{*}{ Bağlilık } & İlkokul & 247 & 15,00 & 6,37 & 270,50 & \multirow{4}{*}{10,232} & \multirow{4}{*}{$0,017^{*}$} \\
\hline & Ortaokul & 131 & 13,56 & 6,06 & 232,77 & & \\
\hline & Lise & 94 & 13,19 & 5,00 & 235,19 & & \\
\hline & Üniversite & 10 & 12,64 & 5,28 & 208,36 & & \\
\hline \multirow{4}{*}{ Güven ve Özdeşim } & İlkokul & 247 & 7,89 & 3,46 & 250,52 & \multirow{4}{*}{0,638} & \multirow{4}{*}{0,888} \\
\hline & Ortaokul & 131 & 7,82 & 3,40 & 248,16 & & \\
\hline & Lise & 94 & 8,06 & 3,51 & 258,30 & & \\
\hline & Üniversite & 10 & 7,32 & 2,75 & 235,07 & & \\
\hline \multirow{4}{*}{ Kendini Açma } & İlkokul & 247 & 10,31 & 3,13 & 254,14 & \multirow{4}{*}{3,912} & \multirow{4}{*}{0,271} \\
\hline & Ortaokul & 131 & 10,29 & 3,08 & 252,75 & & \\
\hline & Lise & 94 & 9,73 & 3,17 & 228,10 & & \\
\hline & Üniversite & 10 & 11,03 & 2,83 & 283,05 & & \\
\hline \multirow{4}{*}{ Sadakat } & İlkokul & 247 & 11,67 & 2,81 & 247,01 & \multirow{4}{*}{4,492} & \multirow{4}{*}{0,213} \\
\hline & Ortaokul & 131 & 12,12 & 2,67 & 271,68 & & \\
\hline & Lise & 94 & 11,41 & 2,86 & 233,85 & & \\
\hline & Üniversite & 10 & 11,61 & 2,54 & 238,11 & & \\
\hline \multicolumn{8}{|l|}{ ASÖ } \\
\hline \multirow{4}{*}{ Hafif Sapma } & İlkokul & 247 & 11,60 & 3,73 & 250,48 & \multirow{4}{*}{1,278} & \multirow{4}{*}{0,734} \\
\hline & Ortaokul & 131 & 11,37 & 3,15 & 246,35 & & \\
\hline & Lise & 94 & 11,67 & 3,95 & 247,73 & & \\
\hline & Üniversite & 10 & 12,82 & 4,47 & 279,32 & & \\
\hline \multirow{4}{*}{ Ağır Sapma } & İlkokul & 247 & 6,49 & 2,20 & 247,39 & \multirow{4}{*}{6,139} & \multirow{4}{*}{0,105} \\
\hline & Ortaokul & 131 & 6,33 & 0,75 & 254,43 & & \\
\hline & Lise & 94 & 6,59 & 2,91 & 240,69 & & \\
\hline & Üniversite & 10 & 7,25 & 3,00 & 292,45 & & \\
\hline
\end{tabular}

${ }^{*} \mathrm{p}<0,05$

Tablo 5'e göre, ergenlerin AİÖ Bağlılık alt boyut puanları ile annelerinin öğrenim durumu arasındaki fark anlamlı bulunmuştur $(\mathrm{p}<0,05)$. Annesi ortaokul ve lise mezunu olanların Bağlılık alt boyut puanı $(\bar{X}=13,56, \bar{X}=13,19)$ annesi ilkokul mezunu olanlara $(\bar{X}=15,00)$ göre istatistiksel olarak anlamlı derecede düşüktür. 
D. Atalay, A. Özyürek

Tablo 6. Baba Öğrenimine Göre AïÖ ve ASÖ Puanları KWH Test Sonuçları

\begin{tabular}{|c|c|c|c|c|c|c|c|}
\hline AİÖ & & $\mathrm{n}$ & Ort. & Ss & Sira Ort. & $\mathrm{H}$ & $p$ \\
\hline \multirow{4}{*}{ Bağl1lık } & İlkokul & 102 & 14,75 & 6,15 & 267,40 & \multirow{4}{*}{2,198} & \multirow{4}{*}{0,532} \\
\hline & Ortaokul & 129 & 13,98 & 5,59 & 251,98 & & \\
\hline & Lise & 196 & 14,05 & 6,23 & 245,22 & & \\
\hline & Üniversite & 73 & 13,90 & 6,23 & 238,44 & & \\
\hline \multirow{4}{*}{ Güven ve Özdeşim } & İlkokul & 102 & 7,81 & 3,63 & 243,60 & \multirow{4}{*}{3,759} & \multirow{4}{*}{0,289} \\
\hline & Ortaokul & 129 & 7,50 & 3,24 & 235,82 & & \\
\hline & Lise & 196 & 7,97 & 3,43 & 254,96 & & \\
\hline & Üniversite & 73 & 8,32 & 3,33 & 274,11 & & \\
\hline \multirow{4}{*}{ Kendini Açma } & İlkokul & 102 & 10,37 & 3,18 & 255,83 & \multirow{4}{*}{0,673} & \multirow{4}{*}{0,080} \\
\hline & Ortaokul & 129 & 10,11 & 3,01 & 244,32 & & \\
\hline & Lise & 196 & 10,15 & 3,21 & 248,60 & & \\
\hline & Üniversite & 73 & 10,49 & 2,96 & 259,07 & & \\
\hline \multirow{4}{*}{ Sadakat } & İlkokul & 102 & 12,19 & 2,57 & 273,78 & \multirow{4}{*}{6,853} & \multirow{4}{*}{0,077} \\
\hline & Ortaokul & 129 & 11,31 & 2,81 & 226,95 & & \\
\hline & Lise & 196 & 11,68 & 2,85 & 248,89 & & \\
\hline & Üniversite & 73 & 12,00 & 2,71 & 263,92 & & \\
\hline \multicolumn{8}{|l|}{ ASÖ } \\
\hline \multirow{4}{*}{ Hafif Sapma } & İlkokul & 102 & 11,79 & 3,41 & 262,66 & \multirow{4}{*}{6,325} & \multirow{4}{*}{0,097} \\
\hline & Ortaokul & 129 & 11,88 & 4,05 & 262,39 & & \\
\hline & Lise & 196 & 11,20 & 3,44 & 230,49 & & \\
\hline & Üniversite & 73 & 12,04 & 3,91 & 266,23 & & \\
\hline \multirow{4}{*}{ A ğır sapma } & İlkokul & 102 & 6,44 & 1,94 & 252,54 & \multirow{4}{*}{0,097} & \multirow{4}{*}{0,992} \\
\hline & Ortaokul & 129 & 6,53 & 2,32 & 250,07 & & \\
\hline & Lise & 196 & 6,43 & 1,41 & 249,14 & & \\
\hline & Üniversite & 73 & 6,78 & 3,42 & 252,06 & & \\
\hline
\end{tabular}

Tablo 6'da görüldüğü gibi AİÖ ve ASÖ puanlarının baba öğrenim durumuna göre anlamlı bir farklılık göstermediği tespit edilmiştir ( $p>0,05)$.

Tablo 7' de ASÖ ve AİÖ puanları arasındaki korelasyon analizleri sonuçları sunulmuştur.

Tablo 7. Ergenlerin AïÖ ve ASÖ Puanları Korelasyon Analizi Sonuçları

\begin{tabular}{lccccc}
\hline ASÖ & Bağlılık & $\begin{array}{c}\text { Güven ve } \\
\text { Özdeşim }\end{array}$ & Kendini Açma & Sadakat \\
\hline Hafif Sapma & $\mathrm{r}$ & 0,233 & 0,192 & 0,039 & $-0,124$ \\
& $\mathrm{p}$ & $0,000^{* *}$ & $0,000^{* *}$ & 0,390 & $0,005^{* *}$ \\
\hline Ağır Sapma & $\mathrm{r}$ & 0,108 & 0,027 & 0,036 & $-0,150$ \\
& $\mathrm{p}$ & $0,015^{*}$ & 0,548 & 0,426 & $0,001^{* *}$ \\
\hline
\end{tabular}

Tablo 7 incelendiğinde, ergenlerin AİÖ Bağlılık alt boyut puanıla ASÖ Hafif ve Ağır Sapma ( $\mathrm{r}=0,233, \mathrm{r}=10,108)$, AİÖ Güven ve Özdeşim Kurma alt boyut puanyla ASÖ Hafif Sapma alt boyut puanları arasında pozitif yönlü zayıf bir ilişki olduğu $(r=0,192, p<0,05)$; AİÖ Sadakat alt boyut puanıla ASÖ Hafif ve Ağır Sapma puanları arasında negatif yönlü zayıf bir ilişki olduğu görülmektedir $(r=-0,123,-0,150, p<0,05)$. Ergenlerin bağlılığ1 arttıkça akran sapmasının arttığ1, sadakati arttıkça akran sapmasının azaldığı, güven ve özdeşim kurma düzeyleri arttıkça hafif akran sapmalarının da arttığı; bir başka deyişle ergenlerin bağlılığı azaldıkça akran sapmalarının azaldığı, sadakatleri azaldıkça akran sapmalarının arttı̆̆ı, güven ve özdeşim kurma düzeyleri azaldıkça hafif akran sapmalarının da azaldığı belirlenmiştir. 


\section{TARTIŞMA}

Çalışmada, arkadaş ilişkilerinde erkeklerin güven ve özdeşim ile sadakat düzeylerinin kız ergenlere göre daha düşük olduğu, kızların arkadaş ilişkilerinde kendini açma düzeylerinin erkeklere göre daha düşük olduğu bulunmuştur. Bu bulguyu destekleyen çalışmalarda kız ergenlerin bağımlılık, güven, özdeşim kurma, sadakat düzeyleri ve arkadaşlık ilişkilerinin erkeklerden daha iyi olduğu belirlenmiştir (Tozkoparan, 2014; Şimsek, 2010; Döğücü, 2004). Moore ve Boldero (1991), çalışmalarında ergenlerin akran ilişkilerinin cinsiyete göre farklılık gösterdiğini ve kız çocuklarının arkadaşlarını erkek çocuklardan daha çok önemseyip yakınlık duyduğunu belirlemişlerdir. Davies ve Brember (1999), kız öğrencilerin iletişimi başlatmada ve sürdürmede problem yaşamadıklarını, arkadaşlarıyla ilişki kurmakta zorlanmadıklarını ve erkek öğrencilere göre arkadaşlarına daha fazla yakınlık duyan ve bağlılık gösteren kişiler olduğunu ifade etmişlerdir. Delikara (2000) ise, erkeklerin kızlara göre sapkın davranışları olan arkadaşlarının yanında daha fazla yer aldıklarını belirlemiştir. Hortaçsu ve Oral (1991) da kızlar çoğunlukla arkadaşlarıyla küçük gruplar şeklinde vakit geçirirken erkeklerin arkadaşlık ilişkilerini kız öğrencilere kıyasla daha büyük gruplar halinde, spor veya benzeri faaliyetler çerçevesinde yürüttükleri belirlenmiştir (Hortaçsu ve Oral, 1991). Farklı bir bulgu olarak Dinçer (2008), akran ilişkilerinde güven ve özdeşim açısından cinsiyet arasında anlamlı bir fark olmadığını belirlemiştir. Çalışma bulguları ve yapılan diğer çalışmalar dikkate alındığında, cinsiyetin arkadaşlık ilişkilerinde belirleyici bir rol oynadığı ve kız ergenlerin erkeklere göre arkadaşlık ilişkilerinin daha anlamlı, erkeklerin arkadaşlık ilişkilerinin ise daha yüzeysel olduğu; erkek ergenlerin ise akran sapmasının kızlara göre daha fazla olduğu söylenebilir. Bu durum, toplumda kız ve erkek çocukların yetiştirilme tarzlarıyla yakından ilişkili olabilir. Geleneksel çocuk yetiştirme tarzlarında kızlardan daha pasif olmaları beklenirken erkeklerin bağımsız davranışları teşvik edilmekte veya kız ve erkek çocuklarının davranışları cinsiyete göre baskı altına alınabilmektedir.

Çalışmada, ergenlerin arkadaşlık ilişkileri ve akran sapması ile kardeş sayıları, annebabalarının yaşı ve öğrenimleri arasında manidar bir fark olmadığı, yalnızca annesi ilkokul mezunu ergenlerin arkadaş ilişkilerinde bağlılık oranının diğerlerinden daha yüksek olduğu saptanmıştır. Bu durum annesi ilkokul mezunu olan ergenlerin, akademik başarılarını artırmak için arkadaş desteğine ihtiyaç duymaları sonucunda arkadaşlarıyla iletişimlerini artırmış ve bağlılık düzeyini etkilemiş olabilmesiyle açıklanabilir. Sorias, Saygılı ve Elbi (1990) kalabalık ve sıkı arkadaşlıkların bireylerde yalnızlık hissini azalttığını, sosyal destek ihtiyacını giderdiğini savunmuştur. Ailenin bireye sağladığı destek arttıkça herhangi bir problem yaşayan arkadaşlarını korumak için yalan söylemek, arkadaşları onun için bir sorun oluştursa dahi onların yanında yer almak anlamina gelen sadakat düzeyinin düştüğü görülmüştür. Twenge ve Campbel (2002) ergenlerde benlik gelişimi üzerine yaptıkları çalışmada, anne ve babaların öğrenim durumunun yüksekliğinin sosyo-ekonomik durumda belirgin bir rahatlama oluşturduğunu ve bu durumun olumlu benlik algısına neden olduğunu, bunun sonucunda ergenlerin arkadaşlık ilişkilerinin daha olumlu ve sağlıklı olduğunu saptamışlardır.

Tozkoparan (2014) çalışmasında akran ilişkilerinin anne-babaların öğrenim düzeyleriyle ilişkili olmadığını, kardeşi olan ergenlerin kardeşi olmayanlara göre arkadaşlık ilişkilerinin daha iyi olduğunu saptamıştır. Dinçer (2008) ise çalışmasında kardeş sayısıyla ve ebeveynlerin öğrenim durumuyla akran ilişkileri arasında anlamlı bir ilişki olmadığını belirlemiştir. Genel olarak kardeş ilişkileri, akran ilişkilerinin belirleyicisi olabilir. Kardeşi olan ergenler, ikili ilişkileri kardeşiyle deneyimlediği için arkadaş ilişkilerinde daha başarılı olması beklenebilir. Bunun yanında, anne ve babaların öğrenim düzeyinin yüksek olması beraberinde sosyo-ekonomik düzeyini olumlu yönde etkilerden sosyal çevreyi de yakından etkileyecektir. Öğrenim düzeyi yüksek ebeveynlerin 


\section{Atalay, A. Özyürek}

çocuklarını daha özgür ve özgüvenli yetiştirmeleri, çocukların sosyal ilişkilerinde daha başarılı olmaları daha olasıdır (Eskicumalı ve Eroğlu, 2001).

Çalışmada, ergenlerin arkadaşlık ilişkilerinde bağlılık düzeyleri arttıkça akran sapmasının arttığı, sadakati arttıkça akran sapmasının azaldığı, güven ve özdeşim kurma düzeyleri arttıkça hafif akran sapmalarının da arttığı belirlenmiştir. Ergenlikte ailenin yerine arkadaşlar alabilmektedir. Böylece belli bazı davranışlara aile yerine arkadaşlar model oluşturabilmektedir. Bu durumda arkadaşlarıyla yakınlık arayışı artan, yani bağlılık düzeyi artan ergenin (Deniz, 2006) arkadaşını model olması ve onu taklit etmesi, dostluk ve bağlılığı ifade ederken sadakatin artmasıyla akran sapmasının azalması (www.tdk.gov.tr) da daha olasıdır.

Bandura'ya göre öğrenme, çevrenin gözlenmesi ve model almayla gerçekleşmektedir. Çevre bireyi, birey de çevreye karşılıklı olarak etkilemekte ve bu etkileşim bireyin davranışını belirlemektedir (Senemoğlu, 2012). Buna göre akran sapması davranışlarının ergenin arkadaşlarıyla ilişkilerden yüksek oranda etkilendiği, bunun sonucunda ergenlerin arkadaşlarını korumak amacıyla başkalarına karşı yıkıcı ve zarar verici davranışlarda bulunma, yasadışı aktivitelere ve çetelere katılma, kavgacılık gibi olumsuz davranışlarda bulundukları düşünülmektedir (Gaviria ve Raphael, 2001). Sosyal bir varlık olan birey, çevresindeki kişilerle iletişim kurma ihtiyacı içerisindedir. Bu aşamada, model alınan kişilerin özellikleri önemli bir unsurdur. Özellikle akranlardan öğrenilen şiddet davranışları ve suça meyilli olma, toplumun genelini etkilemektedir (Ekşi, 2013). Ergenlik döneminin gelişimsel özellikleri de dikkate alındığında arkadaşlık ilişkileriyle akran sapmasının yakından ilişkili olduğu söylenebilir.

Dünyanın neresinde olursa olsun her birey ergenlik dönemini yaşamaktadır. Bu dönemde kimlik kazanımında bireyin kim olduğuna ilişkin soruya cevap bulması beklenir. Ergenlik öncesi dönemde bireyin olumlu yaşantılarla desteklenmesi, ergenlikteki fırtınalı olarak nitelendirilebilecek durumun şiddetini azaltarak ergenin "ben kimim?" sorusunun cevabını bulmasını sağlayacaktır. Bu aşamada, ergenin gereksinimlerini karşılayacak ve onun güvenini kazanmış yetişkinlere ihtiyacı vardır. Aksi halde ergen, kendisi gibi fırtınalı bir dönem yaşayan ve her türlü yönelime hazır akran gruplarında bulabilir (Yapıcı ve Yapıcı, 2005). Bu açıdan bakıldığında, ergenin hem ergenlik dönemini uyumlu şekilde yaşayabilmesi hem de olumlu arkadaşlık ilişkileri için kendisine model olacak, yol gösterecek yetişkinler olarak ailelerine gereksinimi olduğu söylenebilir.

\section{SONUÇ VE ÖNERILER}

Çalışma sonuçlarına göre, erkek ergenlerin arkadaşlık ilişkilerinin daha yüzeysel olduğu ve akran sapmalarının daha fazla olduğu, ergenin arkadaşlık ilişkileriyle akran sapmasının yakından ilişkili olduğu görülmüştür. Bu sonuçlara göre, arkadaşlık ilişkilerinin akran sapması konusunda bir fikir verebileceği söylenebilir.

Bireyler davranışları doğrudan koşullanma, taklit ya da model alarak öğrenirler. Çocukluk döneminde ergenin en yakın çevresi aile iken ergenlikte akranlar daha ön plana çıkmaktadır. Başlangıçta birey için aile bireylerinin davranışlarını model alma ön planda iken ergenlik döneminde akran ilişkilerinin ön plana çıkmasıyla akranların model alınması söz konusu olacaktır. Ergenlik döneminde anne-babanın yerini akranların alması ve bu akranların olumsuz davranışları ergenin olumsuz davranışlara yönelmesinde etkili olacaktır.

Aşağıda, arkadaşlık ilişkilerinin olumlu düzeyde gerçekleşmesi ve akran sapmasıla olumsuz davranışlara yönelmeyi azaltmak için bazı öneriler sunulmuştur.

- Okul öncesi ve oyun çağında, aileler çocuklarıyla çok daha yakından ilgilenirken ergenlik döneminde anne-babalık becerileri konusunda yetersiz kalabilmektedirler. Bu nedenle 
ergenlik dönemi gelişim özellikleri, ergenle iletişim vb. konularında bilgi edinebilirler, okullarda bu konuda rehberlik ve eğitim faaliyetleri yürütülebilir.

- Aile her dönem çocukları için önemli bir rol model olma özelliğini devam ettirir. Çocukların gereksinimlerinin zamanında karşılanması, duygu ve düşüncelerinin önemsenmesi, sevgi ve saygıya dayalı bir aile ortamı sunulması, onların kişiliklerinin belirlenmesinde olumlu etki oluşturacaktır. Gelecekte karşılaştığı durumlar veya kişilerle başa çıkmada kendine güvenli bir kişiliğe sahip olmak ergenin arkadaşlık ilişkilerini yönlendirirken akranlarının toplum tarafından istenmeyen teklif ve davranışlarına karşı koyabilmesini sağlayacaktır. Bu nedenle, anne-babalar çocukları için yetkin ebeveynlik davranışları sergilemeli ve tutarlı olmalıdırlar.

- Okullarda, eğitim-öğretimin faaliyetleri yanı sıra öğrencilere değerler eğitimi eğitimleri verilmesi, arkadaşlık ilişkilerini geliştirebilecekleri ve enerjilerini boşaltabilecekleri sosyal etkinlikler düzenlenebilir.

- $\mathrm{Bu}$ çalışmada arkadaşlık ilişkileri ve akran sapması arasındaki ilişki ergenlerin bakış açısından incelenmiştir. Aile ve öğretmen görüşlerinin ele alındığı ve farklı değişkenlerin dikkate alındığ

Sonuç olarak, günümüzde giderek artan ve artık okullarda da görülmeye başlanan zorbalık davranışlarının artmasında akran etkileşimlerinin etkili olduğu söylenebilir. Bu nedenle gerek aileler gerekse eğitim kurumları özel bir gelişimsel dönem olan ergenlik döneminde, daha duyarlı olmalıdırlar.

Teşekkür: Bu çalışma, Karabük Üniversitesi BAP Birimi tarafından KBÜBAP-17-YL-03 numaralı proje ile desteklenmiştir. Desteğinden dolayı Karabük Üniversitesi BAP birimine teşekkür ederiz.

\section{KAYNAKÇA}

Büyüköztürk, Ş., Kılıç, E., Akgün, Ö.E, Karadeniz, Ş. ve Demirel F. (2016). Bilimsel Araştırma Yöntemleri. Ankara: Pegem.

Çetinkaya, B. (2012). Kişilerarası ilişkiler ve iletişimde kendini açma (Ed: A. Kaya), Kişilerarası İlişsiler ve Etkili İletişim. Ankara: Pegem.

Çevik, G.B, Atıcı, M. (2008). Lise 3. sınıf öğrencilerinin arkadaşlık ilişkilerinin bazı değişkenlere göre incelenmesi, Ç.Ü. Sosyal Bilimler Enstitüsü Dergisi, 17 (2), 35-50.

Davies, J. ve Brember, I. (1999). Boys outperforming girls: A 8 year cross-sectional study of attainment and self-esteem in year 6, Educational Psychology, 19, 5-17.

Delikara, İ. (2000). Ergenlerin akran ilişkileri ile suç kabul edilen davranışlar arasındaki ilişkinin incelenmesi, Yüksek Lisans Tezi, Ankara: A.Ü. Sosyal Bilimler Enstitüsü.

Demir, N., Baran A. ve Ulusoy D. (2005). Türkiye'de ergenlerin arkadaş akran grupları ile ilişkileri ve sapmış davranışlar: Ankara örneklemi, Bilig Dergisi, 32, 83-108.

Deniz, E. (2006), Ergenlerde bağlanma stilleri ile çocukluk istismarları ve suçluluk-utanç arasındaki ilişki. Eurasian Journal of Educational Research, 22, 89-99.

Dinçer, B. (2008). Alt ve üst sosyo-ekonomik düzeyde lise ikinci sınıfa devam eden ergenlerin anne-baba tutumlarını algılamaları ile arkadaşlık ilişkilerinin incelenmesi, Yüksek Lisans Tezi. Ankara: A.Ü. Sosyal Bilimler Enstitüsü.

Döğücü, F. (2004). Tosya ilçesinde farklı liselerde öğrenim gören ergenlerin arkadaş ilişkilerinin incelenmesi. Yüksek Lisans Tezi, Ankara: G.Ü. Eğitim Bilimleri Enstitüsü.

Durmuşoğlu, N. ve Doğru, S. (2006). Çocukluk örseleyici yaşantılarının ergenlikteki yakın ilişkilerde bireye etkisinin incelenmesi. Selçuk Üniversitesi Sosyal Bilimler Enstitüsü Dergisi, 15, 237-246. 


\section{Atalay, A. Özyürek}

Ekşi, H. (2013). Değerler Eğitimi Öğretmen Kitabı, İstanbul: Dostluk.

Eskicumalı, A. ve Eroğlu, E., (2001). Ailenin sosyo-ekonomik ve eğitim düzeyleri ile çocukların problem çözme yetenekleri arasındaki ilişki. Sakarya Üniversitesi Eğitim Fakültesi Dergisi, 1, 160 - 182.

Gaviria, A., Raphael, S. (2001). School-based peer effects and juvenile behavior. The Review of Economics and Statistics, 83, 257-268.

Hartup, W.W. ve Stevens, N. (1997). Friendship and adaptation in the life course, Psychological Bulletin, 121, 355-370.

Hortaçsu, N. ve Oral, A. (1991). Factors affecting relationships of turkish adolescents with parents and same -sex friends, Journal of Social Pschology, 131 (3), 13-14.

http://www.tdk.gov.tr/index.php?option=com_bts\&view=bts\&kategori1=veritbn\&kelimesec=269960.

Kaner, S. (1998). Akran ilişkileri ölçeği ve akran sapması ölçeği geliştirme çalışması. Ankara Üniversitesi Eğitim Bilimleri Fakültesi Dergisi, 33(1-2), 67-75.

Köknel, Ö. (1997). İnsanı Anlamak. İstanbul: Altın Kitaplar.

Moore, S., Boldero, J. (1991). Psychosocial development and friendship functions in adolescence, Sex Roles. 25 (9-10), 521-536.

Sayıl, M., Uçanok, Z. ve Güre, A. (2002). Erken ergenlik döneminde duygusal gereksinimler, aileyle çatışma alanları ve benlik kavramı: betimsel bir inceleme. Çocuk ve Gençlik Ruh Sağglı̆̆ı Dergisi, 9(3), 155-166.

Senemoğlu, N. (2012). Gelişim Öğrenme ve Eğitim: Kuramdan Uygulamaya, Ankara: Pegem A.

Sorias, S., Saygilı, R., Elbi, H. (1990). DSM-III-R Yapılandırılmış Klinik Görüşmesi. Türkçe Versiyonu. SCID-II Kişilik Bozuklukları Formu. Bornova, İzmir: Ege Üniversitesi Basımevi.

Sönmez, V. ve Alacapınar, F. (2011). Bilimsel Araştırma Yöntemleri. Ankara: Anı.

Twenge, J., Campbel, K. (2002). Self esteem and socio economic status. Personality \& Social Psychology, 6, 5972.

Tozkoparan, S. (2014). Öğrenci Algısına Göre Aileden Alınan Sosyal Destek, Anne-Baba Tutumu ve Akran İlişkileri, Yüksek lisans tezi, İstanbul: Maltepe Üniversitesi.

Uz-Baş, A. (2012), Kişilerarası ilişkiler ve iletişimde güvengenlik, (Ed: A. Kaya), Kişilerarası İlişkiler ve Etkili Iletişim. Ankara: Pegem.

Yalom, I.D. (2008). Ergen Terapisi. İstanbul: Prestij.

Yapıcı, Ş. ve Yapıcı, M. (2005). Gelişim ve Öğrenme Psikolojisi, Ankara: Anı. 